\title{
Consortium of endophytic bacteria and rhizobacteria effectively suppresses the population of Pratylenchus coffeae and promotes the growth of Robusta coffee
}

\author{
IIS NUR ASYIAH ${ }^{1, \bullet}$, IMAM MUDAKIR ${ }^{1}$, MOHAMMAD HOESAIN ${ }^{2}$, ANKARDIANSYAH PANDU PRADANA ${ }^{2}$, \\ ACHMAD DJUNAIDY ${ }^{3}$, RIZA FAHLEVIA SARI ${ }^{1}$ \\ ${ }^{1}$ Biology Education Program, Faculty of Teacher Training and Education, Universitas Jember. Jl. Kalimantan No. 37, Jember 68121, East Java, \\ Indonesia. Tel.: +62-331-330738, `email: iisnaza.fkip@unej.ac.id, pandu@unej.ac.id \\ ${ }^{2}$ Plant Protection Program, Faculty of Agriculture, Universitas Jember. Jl. Kalimantan No. 37, Jember 68121, East Java, Indonesia \\ ${ }^{3}$ Plant Protection Program, Faculty of Agriculture, Universitas Trunojoyo. Jl. Raya Telang, Kamal, Bangkalan 69162, East Java, Indonesia
}

Manuscript received: 31 July 2020. Revision accepted: 21 September 2020.

\begin{abstract}
Asyiah IN, Mudakir I, Hoesain M, Pradana AP, Djunaidy A, Sari RF. 2020. Consortium of endophytic bacteria and rhizobacteria effectively suppresses the population of Pratylenchus coffeae and promotes the growth of Robusta coffee. Biodiversitas 21: 4702-4708. Pratylenchus coffeae as the coffee-parasitic nematode can cause a yield loss from $28.7 \%$ to $78.4 \%$ on Robusta coffee (Coffea canephora A. Froehner). Environmentally friendly and sustainable efforts can be made to control this nematode by applying the antagonistic agents from the bacterial group. The application of antagonistic agents in a consortium has a better effectivity than a single application. This study was aimed to identify the effectivity of the consortium of endophytic bacteria and rhizobacteria formulated on a costeffective molasse medium against the $P$. coffeae population and growth of Robusta coffee in a greenhouse. A total of nine bacterial isolates of genus Bacillus and Pseudomonas were used during experiment. The formulation was prepared by mixing the bacterial suspension and $2 \%$ molasses with a ratio of 1:1 (v/v). The greenhouse assay was performed following the completely randomized block design pattern with five treatments and five replications. Robusta coffee plant clone BP 936 was treated with a $10 \mathrm{~mL}\left(10^{9} \mathrm{CFU} \mathrm{mL}^{-1}\right)$ bacterial consortium mixture while control was treated with $10 \mathrm{~mL}$ sterilized water. Each plant was inoculated with $P$. coffeae $50 \mathrm{~J} 2$ after a week of bacterial consortium application. The result showed that all bacterial consortiums were effective in suppressing the population of $P$. coffeae in soil and root of Robusta coffee. All consortiums gave a better result than control in suppressing the population of $P$. coffeae. The best suppression of nematodes was shown by the Cst 02 consortium with the suppression value of $62.5 \%$ in the root and $76.1 \%$ in the coffee plant rhizosphere. The application of bacterial consortium increases the plant height (28.02-44.51\%), number of leaves (127.27-168.18\%), and leaf area (278.8-425.57\%). In this study, suppression of $P$. coffeae population by bacterial consortium showed a positive correlation with plant growth. This study presents the information of endophytic bacteria and rhizobacteria consortium from Bacillus and Pseudomonas group that is effective in suppressing the population P. coffeae and improves the growth of Robusta coffee.
\end{abstract}

Keywords: Bacillus, greenhouse, molasse, Pratylenchus coffeae, Pseudomonas, Robusta coffee

\section{INTRODUCTION}

The plant-parasitic nematode is one limiting factor in coffee production. Three nematode species have been reported to be the primary pathogen on the coffee plant worldwide, namely Meloidogyne incognita, Radopholus similis, and Pratylenchus coffeae (Trinh et al. 2012; Tuyet et al. 2012; Santos et al. 2018). Of those three species, $P$. coffeae is the most prominent nematode due to its distribution and the yield loss of its cause. P. coffeae is reportedly found in all coffee-producing provinces of Indonesia (Indarti and Putra 2018). Low coffee production due to $P$. coffeae infection is about $28.7 \%$ to $78.4 \%$ in Robusta coffee (Coffea canephora A. Froehner). In a separate study, Senthilkumar et al. (2013) reported that Robusta coffee infected by $P$. coffeae could still produce up to five years, but Arabica coffee could only produce up to two years. Arabica coffee had a low-value production of over 95\% (Villain et al. 2000).

The symptoms of $P$. coffeae infection were lesions and necrosis on the root and eventually, lateral root rotted.
(Senthilkumar and Deivamani 2016). Damaged roots disrupt the process of absorption of water and nutrients from soil to the entire plant. Chlorosis occurs in plants due to disruption in the transport of water and nutrients, the symptom (yellowing) begins from the nearest leaves to the stem, then the main branches grow slightly, and the stem is easily shaken due to the depleted root, finally, the plant dies (Villain et al. 2000).

Efforts to control P. coffeae can be made in some ways, namely technical culture, resistant variety use, agrochemical use, and biological control. Although all efforts have been made, the infection of $P$. coffeae s has become an unsolved problem until now. Various studies revealed that one of the promising control for $P$. coffeae is biological control (Munif and Giyanto 2015; Gunasekaran et al. 2018). Prospective biological agents used as biological control of $P$. coffeae generally come from the endophytic bacteria and rhizobacteria (Oliveira et al. 2019).

Endophytic bacteria are those bacteria that can live in plant tissue for their half or whole life cycle without causing symptoms. The interaction occurs between plants, 
and endophytic bacteria are a mutualism interaction (Afzal et al. 2019; Firdous et al. 2019). Previously, six Bacillus sp. of endophytic bacteria have been isolated from Arabica and Robusta coffee. Based on the greenhouse assay, these six isolates of Bacillus sp. could suppress nematode penetration up to $85 \%$ of the coffee plant. In addition, two rhizobacteria i.e. Pseudomonas dimunita and Bacillus subtilis were isolated from coffee plant. These rhizobacterial isolates obtained could also suppress $P$. coffeae population up to $50 \%$ in the Arabica coffee plant (Yulitaasary et al. 2017). The endophytic bacteria and rhizobacteria can protect the coffee plant from $P$. coffeae infection through two mechanisms, i.e. directly and indirectly (Abd-Elgawad 2016). Bacteria can directly produce metabolic compounds as anti-nematodes, such as extracellular enzymes and volatile compounds. The extracellular enzymes reported to suppress the plantparasitic nematodes are protease and chitinase enzyme (Abdel-Salam et al. 2018). The volatile compound as antinematode is hydrogen cyanide (HCN) (Abd El-Rahman et al. 2019). Indirectly, the endophytic bacteria and rhizobacteria can increase plant resistance through induced systemic resistance (ISR) mechanism. ISR is a plant induced resistant phenomenon due to the biological agent stimulation (Mhlongo et al. 2018; Nguvo and Gao 2019). The endophytic bacteria and rhizobacteria can also stimulate plants to produce PR-protein as a resistant compound-complex. Moreover, some biological agents have the ability to fix nitrogen from the environment. Biological agents can also dissolve a bound nutrient elements such as P available to plants (Pham et al. 2017; Bendaha and Belaouni 2020).

The application of biological agent consortium to control plant-parasitic nematodes is generally more effective than a single application. Biological agent consortium is a combination of several biological agents that is mutually compatible and synergetic. The advantage of biological agent consortium is a more diverse mode of actions from the consortium formula made (Munif et al. 2019). Therefore, the endophytic bacteria and rhizobacteria consortium as biological control agents of $P$. coffeae have a great chance to succeed. This study was aimed to identify the effect of endophytic bacteria and rhizobacteria consortium against $P$. coffeae population and to observe the growth of Robusta coffee infected with $P$. coffeae.

\section{MATERIALS AND METHODS}

\section{Isolation of endophytic bacteria and rhizobacteria}

The nine isolates used in this study were previously studied and identified. The detail of these nine isolates is presented in Table 1.

\section{Endophytic bacteria and rhizobacteria consortium formulation on cost-effective molasse medium}

The endophytic bacteria and rhizobacteria were grown on Trypticase Soy Agar (TSA) media for 24 hours at $37^{\circ} \mathrm{C}$. After 24 hours, three loops were taken from each isolate to be used in the formulation stage. The formulation was made by growing the bacteria simultaneously on $100 \mathrm{~mL}$ Trypticase Soy Broth (TSB), then incubated at $37{ }^{\circ} \mathrm{C}$ for 48 hours at $100 \mathrm{rpm}$. After 48 hours, the bacterial suspension grown on TSB media was mixed with a $2 \%$ molasse at the ratio of $1: 1(\mathrm{v} / \mathrm{v})$. This mixture was then called as a bacterial consortium. The bacterial consortium was incubated for 72 hours at $100 \mathrm{rpm}$, after this stage, the bacterial consortium was ready to be used on the next assay (Lobo et al. 2019). The detail of the bacteria used on each consortium is presented in Table 2.

\section{Experimental study}

The study was performed in a greenhouse of Biological Education Study Program, Faculty of Educational Sciences, University of Jember. The plants used were Robusta coffee clone BP 936, with a height of $15 \mathrm{~cm}$ and the number of leaves was three, obtained from the Indonesian Coffee and Cocoa Research Center. Robusta coffee plants were planted on a mixture of soil, sand, and organic matter with the ratio of $1: 1: 1(\mathrm{v} / \mathrm{v} / \mathrm{v})$. The soil characteristic used in this study is presented in Table 3 .

The assay plant was planted on a pot with a diameter of $15.4 \mathrm{~cm}$. An assay was performed following a completely randomized block design pattern with five treatments and five replications, (i) coffee plants infected with nematode and given Cst01 consortium; (ii) coffee plants infected with nematode and given Cst02 consortium; (iii) coffee plants infected with nematode and given Cst03 consortium; (iv) coffee plants infected with nematode and given Cst04 consortium; (v) coffee plants infected with nematode and without bacterial consortium treatment (control).

Table 1. Name of endophytic bacteria and rhizobacteria isolates

\begin{tabular}{lllc}
\hline $\begin{array}{l}\text { Isolate } \\
\text { code }\end{array}$ & Bacterial species & Status & Reference \\
\hline SK07 & Bacillus sp. & Endophyte & \\
SK14 & Bacillus sp. & Endophyte & \\
SK15 & Bacillus sp. & Endophyte & Asyiah et \\
KB11 & Bacillus antrachis & Endophyte & al. (2015, \\
KB14 & Bacillus sp. & Endophyte & 2018) \\
KB63 & Bacillus sp. & Endophyte & \\
PD01 & Pseudomonas dimunita & Rhizobacteria & \\
BS01 & Bacillus subtilis & Rhizobacteria & \\
\hline
\end{tabular}

Table 2. Composition of bacterial consortium

\begin{tabular}{ll}
\hline $\begin{array}{l}\text { Consortium } \\
\text { code }\end{array}$ & Bacterial isolate composition \\
\hline Cst01 & SK07 + SK14 + KB11 \\
Cst02 & SK07 + SK14 + KB14 + PD01 \\
Cst03 & SK07 + SK15 + KB11 + KB14 + KB63 + PD01 \\
& + BS01 \\
Cst04 & SK15 + KB11 + KB14 + KB15 + KB63 + PD 01 \\
& + BS01 \\
\hline
\end{tabular}


Table 3. Soil characteristic for greenhouse assay

\begin{tabular}{llcccc}
\hline Total-N & Total-P & Available-P & Available-K & Organic C & C/N ratio \\
\hline $0.24 \%$ & $16.70{\mathrm{mg} 100 \mathrm{mg}^{-1}}^{-1}$ & $14.65 \mathrm{ppm}$ & $79.82 \mathrm{ppm}$ & $2.39 \%$ & 9.95 \\
\hline
\end{tabular}

One week after planting, the assay plant was given a treatment of bacterial consortium. The application of bacterial consortium was performed by watering $10 \mathrm{~mL}$ $\left(10^{9} \mathrm{CFU} \mathrm{mL} \mathrm{m}^{-1}\right)$ of bacterial consortium on the rooting area of the coffee plant. As a control, the plant was treated with $10 \mathrm{~mL}$ sterilized water. One week after bacterial consortium application, the plant was infested with $P$. coffeae $50 \mathrm{~J} 2$. The treated plants were maintained for 16 weeks (Senthilkumar and Deivamani 2016).

\section{Pathological parameters}

These parameters were used to measure the effectiveness of bacterial consortium as a biocontrol agent against $P$. coffeae. The pathological parameters observed were the number of nematodes in coffee plant roots and soil. Nematode extraction from soil was performed using a White Head Tray method, while the nematode extraction from the root was performed using a mist chamber. The observations were recorded at the 16th week after plant infested with $P$. coffeae $50 \mathrm{~J} 2$.

\section{Plant growth parameters}

These parameters were used to measure the effectiveness of bacterial consortium as a plant growth promoter of the Robusta coffee plant infected with $P$. coffeae. The parameters observed were plant height $(\mathrm{cm})$, number of leaves, and leaf area $\left(\mathrm{cm}^{2}\right)$. The observations were noted at the $16^{\text {th }}$ week after plant infested with $P$. coffeae $50 \mathrm{~J} 2$.

\section{Statistical analysis}

Data were analyzed using an analysis of variance (ANOVA) when a significant difference occurred among treatments; the analysis was continued with Duncan's Multiple Range Test (DMRT) with 95\% degrees of confidence. A program used for analysis was IBM SPSS Statistic 24.0 (Senthilkumar and Deivamani 2016).

\section{RESULTS AND DISCUSSION}

\section{Anti-nematode activity of bacterial consortium}

Bacterial consortium showed better results in the pot assay experiment. The number of nematodes in root or soil on a plant treated with bacterial consortium was significantly different from the control plant (without bacterial consortium treatment) (Table 4). The results showed that the average nematode population on coffee roots in each treatment was 217.6 (Cst 03), 192.6 (Cst 01), 139.4 (Cst 04), 104.4 (Cst 02), and in control it was 371.8. The best performance to suppress the number of $P$. coffeae in root when compared to control was shown by the Cst02 consortium (71.9\%), followed by Cst04 (62.5\%), Cst01
(48.2\%), dan Cst03 (41.5\%). The bacterial consortium also showed a better performance in suppressing the $P$. coffeae population on the Robusta coffee rhizosphere. The average nematode population in the soil was 49 (Cst 01), 25.8 (Cst 02), 37.8 (Cst 03), 27.4 (Cst 04), and 108 (Control). The suppression of nematode population in soil when compared to control was $76.1 \%$ (Cst02) followed by $74.6 \%$ (Cst04), $65 \%$ (Cst03), and $54.6 \%$ (Cst01). The percentage of the nematode population suppression is presented in Table 6 .

Based on the analysis above, all bacterial consortiums were found to be effective in suppressing the $P$. coffeae population either in the coffee root or rhizosphere. Effectiveness was indicated by different superscripts on the Duncan's Multiple Range test result at P-value $\leq 0.05$. Although all consortiums were effective in suppressing the $P$. coffeae population, the $\mathrm{Cst} 02$ consortium showed the stable and best performance among all bacterial consortiums.

Table 4. Effect of bacterial consortium against Pratylenchus coffeae population after 16 weeks of treatment

\begin{tabular}{|c|c|c|}
\hline \multirow{2}{*}{ Treatments } & \multicolumn{2}{|c|}{ P. coffeae population } \\
\hline & Root & Soil \\
\hline Cst 01 & $192.6^{\mathrm{a}} \pm 10.50$ & $49.0^{\mathrm{a}} \pm 3.80^{\mathrm{a}}$ \\
\hline Cst 02 & $104.4^{\mathrm{b}} \pm 15.56$ & $25.8^{\mathrm{b}} \pm 3.70^{\mathrm{b}}$ \\
\hline Cst 03 & $217.6^{\mathrm{a}} \pm 04.56$ & $37.8^{\mathrm{a}} \pm 4.08^{\mathrm{a}}$ \\
\hline Cst 04 & $139.4^{c} \pm 06.42$ & $27.4^{\mathrm{b}} \pm 4.56^{\mathrm{b}}$ \\
\hline Control & $371.8^{\mathrm{d}} \pm 55.25$ & $108.0^{c} \pm 21.77^{c}$ \\
\hline
\end{tabular}

Table 5. Effect of bacterial consortium on the growth of Robusta coffee infected Pratylenchus coffeae

\begin{tabular}{lccc}
\hline Treatments & $\begin{array}{c}\text { Plant height } \\
(\mathbf{c m})\end{array}$ & $\begin{array}{c}\text { Number of } \\
\text { leaves }\end{array}$ & $\begin{array}{c}\text { Leaf area } \\
\left(\mathbf{c m}^{\mathbf{2}}\right)\end{array}$ \\
\hline Cst 01 & $23.4^{\mathrm{a}} \pm 5.80$ & $10.7^{\mathrm{a}} \pm 2.66$ & $416.3^{\mathrm{a}} \pm 224.9$ \\
Cst 02 & $26.3^{\mathrm{a}} \pm 4.37$ & $11.3^{\mathrm{a}} \pm 2.92$ & $577.6^{\mathrm{a}} \pm 260.0$ \\
Cst 03 & $23.3^{\mathrm{a}} \pm 2.05$ & $10.0^{\mathrm{a}} \pm 0.79$ & $200.6^{\mathrm{a}} \pm 103.6$ \\
Cst 04 & $25.9^{\mathrm{a}} \pm 2.74$ & $11.8^{\mathrm{a}} \pm 4.69$ & $345.6^{\mathrm{ab}} \pm 190.6$ \\
Control & $18.2^{\mathrm{b}} \pm 2.97$ & $4.4^{\mathrm{b}} \pm 2.30$ & $109.9^{\mathrm{b}} \pm 81.5$ \\
\hline
\end{tabular}

Note: Values followed by different superscript letters are significant at $\mathrm{P} \leq 0.05$ over control

Tabel 6. Suppression of nematode populations by consortium of endophytic bacteria compared to control plants

\begin{tabular}{lcc}
\hline \multirow{2}{*}{ Treatments } & \multicolumn{2}{c}{ Population suppression (\%) } \\
\cline { 2 - 3 } & Nematodes in root & Nematodes in soil \\
\hline Cst 01 & 48.2 & 54.6 \\
Cst 02 & 71.9 & 76.1 \\
Cst 03 & 41.5 & 65 \\
Cst 04 & 62.5 & 74.6 \\
Control & 0 & 0 \\
\hline
\end{tabular}


Tabel 7. Correlation coefficient between growth variables

\begin{tabular}{|c|c|c|c|c|c|}
\hline & Nematodes in root & Nematodes in soil & Plant height & Number of leaves & Leaf area \\
\hline Nematodes on roots & 1 & & & & \\
\hline Nematodes on soil & $0.960^{* *}$ & 1 & & & \\
\hline Plant height & $-0.994^{* *}$ & $-0.974^{* *}$ & 1 & & \\
\hline Number of leaf & $-0.961^{* *}$ & $-0.976^{* *}$ & $0.964^{* *}$ & 1 & \\
\hline Leaf area & -0.865 & -0.708 & 0.809 & 0.746 & 1 \\
\hline
\end{tabular}

Note: **. Correlation is significant at the 0.01 level (2-tailed)

\section{Growth promoter activity on Robusta coffee infected Pratylenchus coffeae}

All assay plants were in a similar condition and insignificantly different on the initial assay. Plant height, number of leaves, and leaf area were in identical condition in the initial assay. The bacterial consortium showed positive effect on the growth of coffee plants. A significant difference was observed on several growth variables, namely plant height, number of leaves, leaf area, and canopy dry weight. The application of bacterial consortium had a significant effect on plant height compared to the control plant. The best performance to increase plant height was found in the Cst02 bacterial consortium $(26.3 \mathrm{~cm})$, followed by Cst $04(25.9 \mathrm{~cm})$, Cst $01(23.4 \mathrm{~cm})$, dan Cst 03 $(23.3 \mathrm{~cm})$ while in control it was $18.2 \mathrm{~cm}$. The above bacterial consortiums could increase the plant height by 44.51\% (Cst02), 42.31\% (Cst 04), 28.57\% (Cst 01), and $28.02 \%$ (Cst 03). Although all bacterial consortiums gave a significant influence when compared to the control treatment, the plant height among bacterial consortium treatments was not different. This condition indicated that all consortiums had a relatively similar effectivity to increase the plant height.

The application of bacterial consortium also showed positive effect on the number of leaves in Robusta coffee. Based on the observations, plants treated with bacterial consortium had a significantly different number of leaves with the control plants. The bacterial consortium that showed the best performance to increase the number of leaves was Cst 04 (11.8), followed by Cst 02 (11.3), Cst 01 (10.7), and Cst 03 (10) as compared to control where it was 4.4. When compared to the control plant, the above bacterial consortiums could increase the number of leaves by $168.18 \%$ (Cst 04), 156.82\% (Cst 02), 143.18\% (Cst 01), and $127.27 \%$ (Cst 03). The results of the analysis indicated that all treatments were significantly different from the control plant but insignificantly different among treatments. The effectiveness of the endophytic bacteria consortium as plant growth promoter can also be seen from its ability to increase the leaves area of Robusta coffee plants. The results indicated that the two bacterial consortiums i.e. Cst02 and Cst01 showed a significantly different leaf area with control plants. The average leaf area in Cst02 was $577.6 \mathrm{~cm}^{2}$ and in Cst01 it was $416.3 \mathrm{~cm}^{2}$ while the average leaf area in the control was $109.9 \mathrm{~cm}^{2}$. The higher leaf area was recorded in the bacterial consortium of Cst02 (425.57\%) and Cst01 (278.8\%), respectively. The other two consortiums, namely Cst 03 and Cst04, had higher leaf area than the control, these treatments were insignificantly different on the DMRT with $95 \%$ degrees of confidence. Moreover, plant height, number of leaves, and leaf area are presented in Table 5.

\section{Variables correlation}

The number of nematodes in the roots and the number of nematodes in the soil were found to have a correlation with several growth variables. The correlation test result showed a significantly negative correlation between the number of nematodes in soil and root with the plant height. The higher number of nematodes in soil and root, the lower plant height occurred. Based on the correlation test, the number of nematodes in root and soil had a correlation coefficient of $(-0.996$ and -0.974$)$ with plant height, respectively. These coefficient values indicated that the number of nematodes in soil and root had a significant difference in plant height; however, the number of nematodes in root had a greater effect on the plant height.

The number of nematodes in soil and root was negatively correlated with the number of leaves. Due to higher number of nematodes in soil and root, fewer numbers of leaves were occurred. Based on the correlation test, the number of nematodes in root and soil had a correlation coefficient of-0.961 and-0.976 with the number of leaves, respectively. These values indicated that the number of nematodes in soil and root significantly influenced the number of leaves in Robusta coffee; however, the number of nematodes in the root had a more significant effect. Furthermore, the number of nematodes in soil and root were insignificantly correlated with the leaf area. Although high nematode population in soil and root cause low leaf area, this kind of influence was insignificantly different. The correlation among variables is presented in Table 7 and Figure 1. 

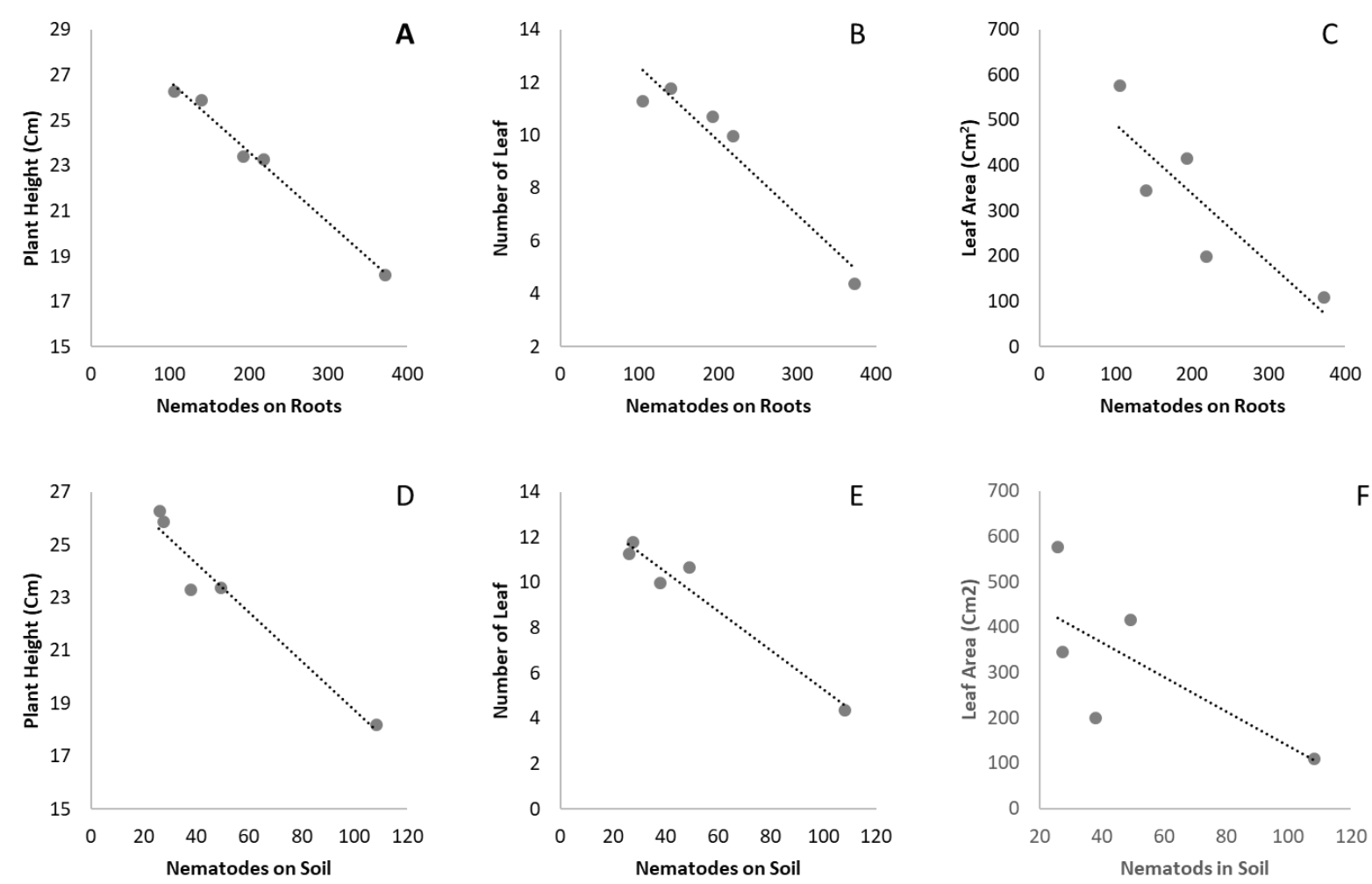

Figure 1. Correlation between the number of nematodes in root and soil with plant growth variables

\section{Discussion}

The suppression of the $P$. coffeae population in soil and root by bacterial consortium can occur directly and indirectly. Rhizobacteria and endophytic bacteria produced secondary metabolites that are directly toxic for nematodes (Thom et al. 2013; Jha and Saraf 2015). The metabolites that are commonly secreted by either rhizobacteria or endophytic bacteria are protease and chitinase extracellular enzymes (Kaur et al. 2013). Protease enzymes can hydrolyze proteins into simple compounds. The hydrolysis result is commonly in the form of peptides or amino acids (Contesini et al. 2018). Several previous researchers have reported the effectiveness of protease enzyme to suppress nematode population and egg hatching. The application of endophytic bacteria and rhizobacteria has been reported to be able to suppress the growth of Meloidogyne incognita (Thongkaewyuan and Chairin 2018), Radopholus similis (Chen et al. 2018), Globodera rostochiensis (López-Lima et al. 2013), and Pratylenchus coffeae nematode (Giribabu et al. 2019). Similarly, protease enzyme, and chitinase enzyme secreted by endophytic bacteria and rhizobacteria also acts as lyase for plant-parasitic nematode cells (Ha et al. 2014). Safni et al. (2018) reported that Pratylenchus spp. of nematode soaked with chitinolytic bacterial filtrate culture, causing damage to the stylet part. The nematode stylet was reported to be abnormal, and some of which were disrupted. Besides extracellular enzymes, endophytic bacteria and rhizobacteria have also been reported to be able to suppress the plant-parasitic nematodes by producing a volatile hydrogen cyanide $(\mathrm{HCN})$ compound (Mardhiana et al. 2017; Munif et al. 2019). The HCN compound is reported to have a nematicidal activity against many plantparasitic nematode types, including Pratylenchus coffeae (Munif and Giyanto 2015).

Endophytic bacteria and rhizobacteria could indirectly induce the plant resistance through an induced systemic resistance (ISR) mechanism. ISR is one of the resistant mechanisms with a broad spectrum. The induced plant produced more resistant compounds than the normal condition (Mhlongo et al. 2018). The resistant compounds commonly produced by plants are phenolic and pathogenesis-related protein (PR-protein) compounds. PRproteins are specific proteins that act as plant resistant compounds from pathogen attack or invasion (I Finkina et al. 2017). In a separate study, Zaynab et al. (2019) reported that plant producing high PR-protein had a higher resistant capability against plant-parasitic nematode infections.

The application of endophytic bacteria and rhizobacteria was also reported to increase coffee plant growth. Bacteria can fix nitrogen from the environment and release it into a form that can be directly utilized by plants. Furthermore, the endophytic bacteria and rhizobacteria can also dissolve phosphate element (P) bonded in soil. Phosphate in the soil is commonly bonded in the form of $\mathrm{P}$ stone or other deposits that are unable to be absorbed directly by plants. Several bacterial groups reportedly capable of fixing $\mathrm{N}$ and dissolving $\mathrm{P}$ are Pseudomonas, Bacillus, Serratia, Paenibacillus, and Micrococcus (Kenneth et al. 2019). 
Endophytic bacteria and rhizobacteria consortium was reported to have a positive effect than the single bacterial application. Bacterial consortiums when applied together increase their effectiveness by more than $30 \%$ compared to individual use (Munif et al. 2019). This statement has been confirmed by Munif and Giyanto (2015), who has compared the application of single bacteria and consortium on the coffee plant. Bacterial consortium gave a better result to suppress the $P$. coffeae population and enhance $\mathrm{e}$ coffee plant growth. The bacterial consortium formulation as biofertilizer and biopesticide with molasse media has also been reported to be effective in the previous studies (Hanudin et al. 2016). Kumari et al. (2019) reported that molasse could be used as cheap formulation media, easily obtained, environmentally safe, capable of supporting bacterial life during the preservation period.

The effectivity of bacterial consortium formula to suppress the nematode population is closely related to the plant growth. Lower nematode population in soil and root can reduce the root damage. Root health is the primary key to plant fertility during the cultivation period. A healthy root can give more optimal results on the nutrient elements and water absorption. Similar results were seen by Avelino et al. (2009) who stated that a higher root damage level by $P$. coffeae caused a more inhibited plant growth. On the other hand, Panneerselvam et al. (2008) reported that the number of $P$. coffeae in the rhizosphere of the coffee plant was positively correlated with the level of coffee roots damage. This study shares the information that endophytic bacteria and rhizobacteria consortium formulated into a cost-effective medium with molasse, which is effective in suppressing the $P$. coffeae population in soil and root of Robusta coffee plant.

\section{ACKNOWLEDGEMENTS}

This research was funded by the University of Jember, Indonesia Fiscal Year 2019 in accordance with the Islamic Development Bank (IDB) Supporting Research Grants (Hibah Penelitian Pendukung IDB).

\section{REFERENCES}

Abd El-Rahman A, Shaheen HA, Abd El-Aziz RM, Ibrahim DS. 2019 Influence of hydrogen cyanide-producing rhizobacteria in controlling the crown gall and root-knot nematode, Meloidogyne incognita. Egypt J Biol Pest Control 29: 41. DOI: 10.1186/s41938-019-0143-7.

Abd-Elgawad M. 2016. Biological control agents of plant-parasitic nematodes. Egypt J Biol Pest Control 26 (2): 423-429.

Abdel-Salam M, Ameen HH, Soliman GM, Elkelany U, Asar AM. 2018 Improving the nematicidal potential of Bacillus amyloliquefaciens and Lysinibacillus sphaericus against the root-knot nematode Meloidogyne incognita using protoplast fusion technique. Egypt $\mathrm{J}$ Biol Pest Control 28 (1): 1-6.

Afzal I, Shinwari ZK, Sikandar S, Shahzad S. 2019. Plant beneficial endophytic bacteria: mechanisms, diversity, host range and genetic determinants. Microbiol Res 221: 36-49.

Asyiah IN, Soekarto, Husain M, Iqbal M, Hindersah R, Narulita E, Mudakir I. 2018. The endophytic bacteria isolation as biological control agent of Pratylenchus coffeae. Asian Journal of Microbiology, Biotechnology and Environmental Sciences 20 (1): 165-171.
Asyiah IN, Wiryadiputra S, Fauzi I, Harni R. 2015. Populasi Pratylenchus coffeae (Z.) dan pertumbuhan bibit kopi Arabika akibat inokulasi Pseudomonas dimunita L. dan Bacillus subtilis (C.). Pelita Perkebunan 31 (1): 30-40. [Indonesian]

Avelino J, Bouvret M-E, Salazar L, Cilas C. 2009. Relationships between agroecological factors and population densities of Meloidogyne exigua and Pratylenchus coffeae sensu lato in coffee roots, in Costa Rica. Appl Soil Ecol 43 (1): 95-105.

Bendaha M, Belaouni H. 2020. Effect of the endophytic plant growthpromoting Enterobacter ludwigii EB4B on tomato growth. Hell Plant Prot J 13 (2): 54-65.

Chen D, Wang D, Xu C, Chen C, Li J, Wu W, Huang X, Xie H. 2018. Nematicidal protease genes screened from a soil metagenomic library to control Radopholus similis mediated by Pseudomonas fluorescens pf36. Appl Microbiol Biotechnol 102 (7): 3301-3314.

Contesini FJ, Melo RRd, Sato HH. 2018. An overview of Bacillus proteases: from production to application. Crit Rev Biotechnol 38 (3): 321-334.

Firdous J, Lathif NA, Mona R, Muhamad N. 2019. Endophytic bacteria and their potential application in agriculture: a review. Indian J Agric Res 53 (1): 1-7.

Giribabu P, Thangavelu R, Anitha-Sree T. 2019. Evaluation of biocontrol agents against root-lesion (Pratylenchus coffeae) and root-knot (Meloidogyne incognita) nematodes infecting Banana (Musa sp.). Indian J Nematol 49 (2): 179-186.

Gunasekaran T, Alagersamy A, Suthanthiram B, Thangaraj A, Palaniyandi S, Subramanian M. 2018. Cloning of the defense gene PlchilII and its potential role in the biocontrol of Pratylenchus coffeae nematodes and Meloidogyne incognita eggs in Musa. Biocatalysis Agric Biotechnol 16: 604-613.

Ha WJ, Kim YC, Jung H, Park SK. 2014. Control of the root-knot nematode (Meloidogyne spp.) on cucumber by a liquid bioformulation containing chitinolytic bacteria, chitin and their products. Res Plant Dis 20 (2): 112-118.

Hanudin H, Nawangsih AA, MarwotoB, Tjahjono B. 2016. Komposisi formula biobakterisida berbahan aktif rizobakteri untuk pengendalian penyakit busuk lunak pada anggrek phalaenopsis. Jurnal Hortikultura 23 (3): 244-254. [Indonesian]

I Finkina E, N Melnikova D, V Bogdanov I, V Ovchinnikova T. 2017. Plant pathogenesis-related proteins PR-10 and PR-14 as components of innate immunity system and ubiquitous allergens. Curr Med Chem 24 (17): 1772-1787.

Indarti S, Putra NS. 2018. Abundance and diversity of plant-parasitic nematodes associated with BP 308 and BP 42 clones of Robusta coffee in Java, Indonesia. Biodiversitas J Biol Divers 19 (1): 67-70.

Jha CK, Saraf M. 2015. Plant growth-promoting rhizobacteria (PGPR): a review. J Agric Res Dev 5 (2): 108-119.

Kaur T, Sharma D, Kaur A, Manhas RK. 2013. Antagonistic and plant growth-promoting activities of endophytic and soil actinomycetes. Arch Phytopathol Plant Prot 46 (14): 1756-1768.

Kenneth OC, Nwadibe EC, Kalu AU, Unah UV. 2019. Plant growthpromoting rhizobacteria (PGPR): a novel agent for sustainable food production. Am J Agric Biol Sci 14: 35-54.

Kumari S, Bharat NK, Chauhan D. 2019. Efficacy of PGPR and Trichoderma on growth and yield parameters of bell pepper (Capsicum annuum L.). J Plant Dev Sci 11 (9): 493-499.

Lobo CB, Tomás MSJ, Viruel E, Ferrero MA, Lucca ME. 2019. Development of low-cost formulations of plant growth-promoting bacteria to be used as inoculants in beneficial agricultural technologies. Microbiol Res 219: 12-25.

López-Lima D, Sánchez-Nava P, Carrión G, Núñez-Sánchez AE. 2013. $89 \%$ reduction of a potato cyst nematode population using biological control and rotation. Agron Sustain Dev 33 (2): 425-431.

Mardhiana M, Pradana AP, Adiwena M, Santoso D, Wijaya R, Murtilaksono A. 2017. Use of endophytic bacteria from roots of Cyperus rotundus for biocontrol of Meloidogyne incognita. Biodiversitas J Biol Divers 18 (4): 1308-1315.

Mhlongo MI, Piater LA, Madala NE, Labuschagne N, Dubery IA. 2018. The chemistry of plant-microbe interactions in the rhizosphere and the potential for metabolomics to reveal signaling related to defense priming and induced systemic resistance. Front Plant Sci 9: 1-17. DOI: $10.3389 / \mathrm{fpls} .2018 .00112$.

Munif A, Giyanto G. 2015. Effectiveness of endophytic bacterial consortium of coffee plant on mortality of Pratylenchus Coffeae in Vitro. Pelita Perkebunan 31 (3): 175-185. [Indonesian] 
Munif A, Herliyana EN, Pradana AP. 2019. Endophytic bacterial consortium originated from forestry plant roots and their nematicidal activity against Meloidogyne incognita infestation in greenhouse. Acta Universitatis Agriculturae et Silviculturae Mendelianae Brunensis 67 (5): 1171-1182.

Nguvo KJ, Gao X. 2019. Weapons hidden underneath: bio-control agents and their potentials to activate plant induced systemic resistance in controlling crop Fusarium diseases. J Plant Dis Prot 126 (3): 177-190.

Oliveira KCLd, Meneses ACd, Silva JM, Tavares RLC. 2019. Biological management of Pratylenchus brachyurus in soybean crops. Revista Caatinga 32 (1): 41-51.

Panneerselvam P, Thangaraju M, Senthilkumar M. 2008. Microbial consortium and its effect on controlling coffee root-lesion nematode (Pratylenchus coffeae) under nursery conditions. J Biol Control 22 (2): 425-432.

Pham VT, Rediers H, Ghequire MG, Nguyen HH, De Mot R, Vanderleyden J, Spaepen S. 2017. The plant growth-promoting effect of the nitrogen-fixing endophyte Pseudomonas stutzeri A15. Arch Microbiol 199 (3): 513-517.

Safni I, Lubis K, Tantawi AR, Murthi S. 2018. Isolation and characterization of rhizobacteria for biological control of root-knot nematodes in Indonesia. J ISSAAS 24: 67-81.

Santos MF, Salgado SM, Silva JG, Correa VR, Mendonça JS, Carneiro RM. 2018. Meloidogyne incognita parasitizing coffee plants in southern Minas Gerais, Brazil. Trop Plant Pathol 43 (1): 95-98.

Senthilkumar P, Deivamani M. 2016. Management of lesion nematode, Pratylenchus coffeae in coffee plants treated with native rhizobacteria under subtropical conditions. Ann Plant Prot Sci 24 (1): 160-162.
Senthilkumar P, Nagesvari K, Revathi E, Prabhu S. 2013. Reaction of coffee plants against lesion nematode, Pratylenchus coffeae treated with bacterial consortium under Hilly regions of Shervaroys. Indian J Nematol 43 (2): 152-155.

Thom ER, Popay AJ, Hume DE, Fletcher LR. 2013. Evaluating the performance of endophytes in farm systems to improve farmer outcomes-a review. Crop Pasture Sci 63 (10): 927-943.

Thongkaewyuan A, Chairin T. 2018. Biocontrol of Meloidogyne incognita by Metarhizium guizhouense and its protease. Biol Control 126: 142146.

Trinh PQ, Waeyenberge L, Nguyen CN, Moens M. 2012. Morphological and molecular diversity of Radopholus on coffee in Vietnam and description of $R$. daklakensis $\mathrm{sp}$. n. from Robusta coffee. Nematology 14 (1): 65-83.

Tuyet NT, Elsen A, Nhi HH, De Waele D. 2012. Morphological and morphometrical characterisation of ten Pratylenchus coffeae populations from Vietnam. Russ J Nematol 20(1): 75-93.

Villain L, Molina A, Sierra S, Decazy B, Sarah JL. 2000. Effect of grafting and nematicide treatments on damage by the root-lesion nematode Pratylenchus spp. on Coffea arabica L. in Guatemala. Nematropica 30 (1): 87-100.

Yulitaasary AT, Asyiah IN, Iqbal M. 2017. Isolasi dan identifikasi Azotobacter dari rhizosfer tanaman kopi (Coffea canephora) yang terserang nematoda parasit Pratylenchus coffeae. Saintifika 19 (2): 13-23. [Indonesian]

Zaynab M, Fatima M, Abbas S, Sharif Y, Umari M, Zafar MH, Bahadar K. 2018. Role of primary metabolites in plant defense against pathogens. Microb Pathog 124: 198-202. 